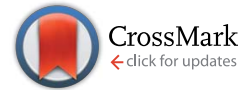

Cite this: J. Anal. At. Spectrom., 2016, 31,1047

DOI: 10.1039/c6ja90015a

www.rsc.org/jaas

\section{Correction: Sulfur isotope analysis by MC-ICP-MS and application to small medical samples}

Emmanuelle Albalat, ${ }^{a}$ Philippe Telouk, ${ }^{a}$ Vincent Balter, ${ }^{a}$ Toshiyuki Fujii, ${ }^{b}$ Victor Paky Bondanese, ${ }^{a}$ Marie-Laure Plissonnier, ${ }^{c}$ Virginie Vlaeminck-Guillem, ${ }^{d}$ Justine Baccheta, ${ }^{e}$ Ndiémé Thiam, ${ }^{f}$ Pierre Miossec, ${ }^{f}$ Fabien Zoulim, ${ }^{c}$ Alain Puisieux ${ }^{g}$ and Francis Albarède ${ }^{\star a}$

Correction for 'Sulfur isotope analysis by MC-ICP-MS and application to small medical samples' by Emmanuelle Albalat et al., J. Anal. At. Spectrom., 2016, DOI: 10.1039/c5ja00489f.

The authors regret the misspelling of Victor Paky Bondanese's name.

The Royal Society of Chemistry apologises for these errors and any consequent inconvenience to authors and readers. 